\title{
Arts majors as entrepreneurs and innovators
}

\author{
Richard J. Paulsen (D) - Neil Alper (D) \\ Gregory Wassall (1)
}

Accepted: 8 September 2020 / Published online: 27 October 2020

(C) Springer Science+Business Media, LLC, part of Springer Nature 2020

\begin{abstract}
This study examines the role of college graduates with degrees in the arts, STEM, and other creative fields as entrepreneurs and innovators in the US economy. As creativity is a trait of art students and is important for those acting as entrepreneurs and innovators in an economy, arts majors have the potential to play an important role in these areas. Using American Community Survey data, we look to identify arts, STEM, and other creative majors who are working in entrepreneurial occupations, those where self-employment is common, and innovative industries, those that are copyright intensive. As it is possible that the nature of arts occupations may be inherently more entrepreneurial and innovative, we compare arts majors to STEM and other creative majors also likely to work in such occupations. Using logistic regression, we find that majoring in a core arts field more than doubles an individual's likelihood of working in an entrepreneurial occupation or an innovative industry relative
\end{abstract}

Electronic supplementary material The online version of this article (https://doi.org/10.1007/s11187-020-00416-x) contains supplementary material, which is available to authorized users.

R. J. Paulsen $(\bowtie)$

Department of Economics, Bloomsburg University of Pennsylvania, 228 Sutliff Hall, 400 E 2nd Street, Bloomsburg, PA, USA

e-mail: rpaulsen@bloomu.edu

N. Alper · G. Wassall

Department of Economics, Northeastern University, Boston, MA, USA to non-creative majors. Other creative majors, like communications and STEM majors, are also associated with an increased likelihood of working as entrepreneurs or innovators. Relative to STEM and other creative majors, majoring in a core arts field is associated with the greatest increase in the likelihood of working in an entrepreneurial occupation and third greatest increase in the likelihood of working in an innovative industry. While arts graduates play an important role in artistic creation, this paper highlights a role for these graduates as entrepreneurs and innovators in the US economy.

Keywords Entrepreneurship · Innovation · Arts · Arts majors

JEL classifications $\mathrm{J} 24 \cdot \mathrm{L} 26 \cdot \mathrm{O} 34 \cdot \mathrm{Z} 11$

\section{Introduction}

Innovation and entrepreneurship are terms often associated with economic growth. Entrepreneurs create new businesses that can spur employment and economic growth (Fölster 2000). Innovation, through the development of intellectual property, also has the potential to spur economic growth (Park 2010; Towse et al. 2008). Since entrepreneurs generate new business ideas and innovators generate new works of intellectual property, creativity is important in determining success as an entrepreneur or an innovator (Kritikos 2014). One group of college graduates for whom creativity is an integral 
part of education are arts majors (Tepper and Kuh 2011). However, their role in entrepreneurship and innovation has not been studied.

The role of entrepreneurs and innovators in economic growth increasingly aligns with the creation of small businesses (Kritikos 2014). Economic activity shifted from large to small firms in the USA in the late twentieth century. Fortune 500 companies accounted for $20 \%$ of employment in 1970; they accounted for $8.5 \%$ in 1996 (Carlsson 1999). In 2016, the USA had approximately 5.6 million firms. The majority of these were small businesses; $89.0 \%$ employed fewer than 20 workers and $98.2 \%$ employed fewer than 100 workers. Small businesses contribute substantially to employment and the creation of intellectual property ("Facts \& Data on Small Business and Entrepreneurship" 2018). Firms with few employees are especially common within artistic and creative industries (Bujor and Avasilcai 2014). Arts entrepreneurship and promotion of the arts have increasingly been used as strategies to create economic development and to attract other industries and high-skilled workers (Phillips 2010).

To understand the role arts majors play in entrepreneurship and innovation in the US economy, we use American Community Survey (ACS) data. We find considerable evidence of this role. Arts majors are far more likely to work in an entrepreneurial occupation or an innovative industry than college graduates on average. While just under $20 \%$ of college graduates work in entrepreneurial occupations and just under $10 \%$ work in innovative industries, having an arts major more than doubles the likelihood of each. Many STEM and other creative majors are also more likely to work in entrepreneurial occupations or innovative industries.

We present findings for STEM and other creative majors in addition to arts majors for two reasons. First, STEM and other creative majors are likely to involve creative thinking. Understanding the role graduates of these majors play in entrepreneurship and innovation is important. Second, the careers that arts majors pursue may be intrinsically more entrepreneurial and innovative than those of college graduates generally. By comparing arts majors to STEM and other creative majors who are also likely to pursue fields that are intrinsically more entrepreneurial and innovative, our findings that arts majors compare favorably to persons in these fields holds greater value.

\section{Literature review}

In the literature review, we discuss five topics. We begin with the literature on the careers of arts majors. Second, we review the literature on the definition and identification of entrepreneurs. Third, we explore the theoretical and empirical work connecting entrepreneurship and self-employment. Fourth, we examine innovation. Last, we summarize the key takeaways of these sections and tie them to our study.

\subsection{Careers of arts majors}

The careers of arts majors have been examined using large-scale surveys, such as the Strategic National Arts Alumni Project (SNAAP) survey, the American Community Survey (ACS), and national surveys outside the USA.

Lindemann et al. (2012), Lena et al. (2014), Gerber and Childress (2017), and Frenette and Dowd (2018) use the SNAAP data to analyze the career experience of US arts graduates. Lindemann et al. (2012) find that more than half of arts graduates hold jobs associated with the arts. For the others, $60 \%$ report that their arts training is relevant to their jobs. Over $60 \%$ of respondents had previously been or were currently selfemployed, working freelance or working as independent contractors. A small number of respondents had also founded companies. Lena et al. (2014) find that among recent graduates, the most common reasons for not working as professional artists were that artistic work was not available, that they held higher paying or steadier jobs in other fields, or that they had debt. For nonrecent graduates, having a higher paying or steadier job was the most common reason. Gerber and Childress (2017) use SNAAP data to highlight the roles of arts graduates in teaching and serving other functions in non-profit settings. Frenette and Dowd (2018) use SNAAP data to determine what predicts employment in the arts for arts graduates. Being male and being white are both positively predictive of arts employment. Having a double major where an arts and non-arts major are paired decreases the likelihood of employment in the arts, while having a graduate arts degree increases this likelihood.

Wassall and Alper (2018) and BFAMFAPhD (2014) use ACS data to study the occupations and earnings of US arts graduates. Approximately $40 \%$ of working artists do not have any college degree, and most college 
educated artists have a degree in a field outside the arts. Among arts majors, a majority work in non-arts occupations. For those working in the arts, having an arts major leads to an earnings premium. However, earnings for arts majors are low relative to most other college graduates.

Bille and Jensen (2018), using Danish data, examine which factors influence whether an individual is employed in the arts. Their primary finding is that for three of five groups of art occupations, having a college degree in an arts major is a significant predictor of remaining employed in the arts. Rengers (2002) looks at the employment and earnings of arts graduates in the Netherlands. Having a partner is found to increase the likelihood of being employed, while having children is found to decrease it.

\subsection{Entrepreneurship/entrepreneurs}

What is entrepreneurship, and who are entrepreneurs? These concepts lack universally accepted definitions. The Center for American Entrepreneurship states that "Entrepreneurship is an elusive concept to pin down" ("What is Entrepreneurship?" n.d.). This is because entrepreneurship is a concept that is studied by a diverse range of disciplines, with differing foci and differing vocabulary.

Economists' dominant definition of the entrepreneurial process is from Schumpeter (Audretsch 2003). Schumpeter viewed entrepreneurship as a process that leads to marketplace disequilibrium rather than equilibrium. A difficulty in defining the entrepreneurial process suggested by Audretsch (2003) is that it can involve a variety of organizational structures. In the arts, it can involve the activities of an individual, groups of individuals, projects, the production of a performance, and firms that are either for-profit or not-for-profit.

A universally accepted definition of entrepreneurs is difficult to come up with. An all-encompassing definition comes from Dictionary.com: "Entrepreneurs, in the purest sense, are those who identify a need-any need - and fill it. It's a primordial urge, independent of product, service, industry or market" (Nelson 2012). A definition that's more economics focused is: “... a person, who through innovation and/or insight, adds value to a product or service and moves it to a higher level of economic return" (Radich 2014). Radich (2014) identifies social entrepreneurs who produce products or services that do not necessarily generate higher levels of economic return but benefit specific groups or society as a whole. These entrepreneurs are in government, education, and politics. They innovate and take risks but create non-monetizable benefits from the products and services they produce. Taken collectively, entrepreneurship is a process of new creation, with entrepreneurs as the creators.

Defining entrepreneurs empirically is generally much simpler and frequently revolves around selfemployment (Christnacht et al. 2018). According to Blanchflower and Oswald (2007), "(t)he most commonly studied class of entrepreneurs is those who are selfemployed." This is especially true for studies that use national samples of the labor force. Blanchflower and Oswald (2007) study self-employed entrepreneurs using labor force surveys for the UK, Canada, and the USA. In a separate study of US self-employed entrepreneurs, Blanchflower expands the definition to include people who own small firms (Blanchflower 2007).

Woronkowicz and Noonan (2019) provide a review of the empirical literature describing what is known about the basic characteristics of self-employed entrepreneurs. This includes education, labor market characteristics, family and individual financial matters, earnings, and demographic characteristics. Blanchflower and Oswald (2007) find that having a self-employed parent is positively correlated with selfemployment. A recent study by the Kauffman Foundation on early-stage entrepreneurs finds a negative correlation between educational attainment and becoming a new entrepreneur. It also finds that immigrants are twice as likely to become new entrepreneurs as native born (Fairlie et al. 2019). From a sample of US residents with scientific bachelors' degrees, Kahn et al. (2017) find an immigrant entrepreneurship premium. Lazear's study of MBA graduates finds that "(e)ntrepreneurs are individuals who are multifaceted. Although not necessarily superb at anything, entrepreneurs have to be sufficiently skilled in a variety of areas to put together the many ingredients required to create a successful business. As a result, entrepreneurs tend to be more balanced individuals" (Lazear 2005).

\subsection{Self-employed}

Due to the empirical relationship between selfemployment and entrepreneurship, it is important to understand what it means to be self-employed. Szaban and Skrzek-Lubasinska (2018) classify the self- 
employed into five categories: dependent selfemployed, hybrid self-employed, one-person replicative business owners, one-person innovative start-up owners, and freelancers/individual professionals. These five groups differ in their level of entrepreneurship. Innovative start-up owners meet all but one of 33 characteristics of entrepreneurship. Business owners and freelancers also meet most characteristics, while hybrid self-employed and dependent self-employed meet fewer than half the characteristics (Szaban and SkrzekLubasinska 2018). Two factors that may determine the type of self-employment a person may engage in are educational status and the stage of the business cycle.

The link between self-employment and entrepreneurship has been tested empirically. A study of the selfemployed in Andalusia found that about 60\% innovated or acted in an entrepreneurial way and that the likelihood of innovating was positively related to education (Plotnikova et al. 2016). An empirical study of German workers found that relative to other workers, selfemployed workers perform more tasks, and those tasks performed require more skill (Lechmann and Schnabel 2014).

\subsection{Innovation/innovators}

Like defining entrepreneurship, defining innovation is also difficult. The Merriam-Webster dictionary defines innovation as "the introduction of something new" or "a new idea, method, or device: novelty" ("Innovation" 2020). Innovation is a term that has different meanings across disciplines, like entrepreneurship. This interdisciplinarity is a key factor in the difficulty of formulating a universal definition.

Baregheg et al. (2009) present a multidisciplinary definition of innovation. The authors examine what language these definitions have in common. When defining the nature of innovation, "new" is by far the most frequently used word. "Change" and "improve" are the second and third most frequent. In defining the means of innovation, the terms "idea," "invention," "technology," "market," and "creativity" all occur at high frequencies. In defining the type of innovation, the terms "product," "service," "process," and "technical" occur most frequently. Innovations are new, changed, or improved products, services, or processes, and the process of innovation involves generating ideas and being creative.

Measuring innovation creates fewer challenges. Works of intellectual property are frequently used as measures of innovation (Teese 2018; Park 2010; Towse et al. 2008). Intellectual property law protects creators of physical products through the awarding of patents, creators of artistic works through copyrights, and creators of brands through trademarks. While patents, copyrights, and trademarks may not exhaustively encompass all innovation that occurs within an economy, these do serve as quantifiable starting points to measure innovation.

\subsection{Summary}

The literature on the careers of arts majors finds that most work outside the arts and many are self-employed. The importance of creativity in both entrepreneurship and innovation makes them candidates to contribute in these areas. In defining entrepreneurship and innovation empirically, it is common to relate self-employment to entrepreneurship and intellectual property to innovation. While not perfect measures of these concepts, we will use these in our empirical definitions.

\section{Data}

\subsection{The American Community Survey}

Our principal data source is the Census Bureau's American Community Survey (ACS). ${ }^{1}$ The ACS is an annual survey of US residents; it began after the completion of the 2000 Census. A unique random sample of households is chosen every year; the samples can be appropriately weighted using Census population weights to combine ACS Public Use Micro Sample (PUMS) data from different years. We use a combined 2013-2017 ACS PUMS as our primary source of data.

The primary reason we use the ACS is that beginning with the 2009 survey, it collected information about the major field of study from survey participants who graduated 4-year colleges. The ACS recognizes just over 150 majors. Also, the ACS PUMS contains up to two major codes for each college graduate. Thus, persons who were double majors are identified by both major codes. In addition, the size of the 5-year sample allows for reliable estimates for detailed majors, such as arts majors.

\footnotetext{
${ }^{1}$ For a detailed description of the American Community Survey, see https://www.census.gov/programs-surveys/acs.
} 
There is no accepted set of college majors that can be called arts majors. We employ two definitions. The first set, called "core arts majors," consists of nine majors likely to be considered classic arts majors: fine arts; drama and theater arts; music; visual and performing arts; commercial art and graphic design; film, video, and photographic arts; art history and criticism; studio arts; and miscellaneous fine arts. ${ }^{2}$ The architecture major is also included in this group because architects are one of the National Endowment for the Arts' eleven arts occupations.

The second group, "extended arts majors" encompasses language and drama education; art and music education; English language and literature; and composition and speech. These four majors have less artistic content, but they provide skills that would help graduates enter artistic fields.

\subsection{Descriptive statistics}

Table 1 presents descriptive statistics for the sample of college graduates. The full sample contains approximately 2.6 million observations. Using sampling weights, ${ }^{3}$ the population of college graduates is estimated at 52.4 million. The first column presents results for the population of college graduates. The second and third columns present comparable data for core arts majors and extended arts majors. Core arts majors comprise $5.4 \%$ of the sample, while extended arts majors comprise $4.3 \%$. Relative to all college graduates, arts majors are less likely to be employed, more likely to be employed part-time, and have lower earned income conditional on being employed. Relative to core arts majors, extended arts majors are more likely to be employed and have higher earned income conditional on being employed. Self-employment is more common among arts majors than all college graduates.

Arts majors also differ significantly from the all college graduates in many demographic characteristics. Relative to the full sample, core arts majors are less likely to be male, more likely to be white, and less likely to be married. Core arts majors are less likely to have a degree beyond a bachelor's. Extended arts majors are more likely to have a higher degree.

\footnotetext{
$\overline{2}$ Table A-1 in the Online Appendix gives detailed codes for all major groupings.

${ }^{3}$ The ACS variable PERWT variable is used for frequency weights in all calculations.
}

Most arts majors do not work directly in the arts. Wassall and Alper (2018), using a 2009 to 2013 combined sample from the ACS, find that depending on one's definition of arts major, between 15 and $25 \%$ of all arts majors work as artists in the USA. This finding is consistent with our updated data. In Table A - 2 in the Online Appendix, we see that $23.9 \%$ of core arts majors work in arts and entertainment occupations and $16.7 \%$ of all arts majors (core plus extended) work in these occupations. As for industry of choice for arts majors, Online Appendix Table A - 3 shows that less than 7\% work in arts, entertainment, and recreation.

\section{Entrepreneurship and innovation}

\subsection{Entrepreneurship}

Following the literature on entrepreneurship, we use self-employment in defining entrepreneurship when examining the role of majoring in the arts in entrepreneurship.

The ACS reports on 539 unique occupations and places them into 23 major occupation groups. ${ }^{4} \mathrm{We}$ impose a cutoff, defining an entrepreneurial occupation as any that has at least $20 \%$ self-employment. ${ }^{5}$ This left 84 four-digit ACS occupations ${ }^{6}$ with "farmers, ranchers and other agricultural managers" having the highest percentage self-employed (84\%) and "electronic home entertainment equipment installers and repairers" having the lowest (20\%). One of the top five entrepreneurial occupations, "artists and related workers" (60\% selfemployed), is in the "artists and entertainers" major occupation group, as is the "editors" occupation (20\% self-employed). Our analysis is based on the aggregation of these occupations into their appropriate major occupation groups, 16 of the 23 in the ACS.

The following tables show the distribution of college graduates in entrepreneurial occupations. Table 2 provides this information for core and extended arts majors. Table 3 provides the same information for STEM and other creative majors.

\footnotetext{
${ }^{4}$ For more information, see "Industry and Occupation," www.census. gov/topics/employment/industry-occupation/about/occupation. html\#\#targetText=This\%20system \%20 consists \%20of\%20539 ,into\%2023\%20major\%20occupational\%20groups.

${ }^{5}$ Our primary findings are robust to using 15 and $25 \%$ as cutoffs.

${ }^{6}$ See appendix Table A -4 for a detailed list of the 84 entrepreneurial occupations and the 16 major occupation groups.
} 
Table 1 Descriptive statistics

\begin{tabular}{|c|c|c|c|}
\hline Variable & $\begin{array}{l}\text { Full } \\
\text { sample }\end{array}$ & $\begin{array}{l}\text { Core arts } \\
\text { majors }\end{array}$ & $\begin{array}{l}\text { Extended } \\
\text { arts majors }\end{array}$ \\
\hline Employed & $96.7 \%$ & $95.5 \%$ & $96.3 \%$ \\
\hline Part-time & $15.2 \%$ & $22.4 \%$ & $21.3 \%$ \\
\hline Self-employed & $10.2 \%$ & $17.5 \%$ & $11.3 \%$ \\
\hline Earned income & $\$ 77,159$ & $\$ 57,689$ & $\$ 63,896$ \\
\hline Male & $49.6 \%$ & $45.4 \%$ & $34.9 \%$ \\
\hline Age & 43.4 & 41.7 & 44.8 \\
\hline White & $79.5 \%$ & $84.5 \%$ & $86.9 \%$ \\
\hline Black & $9.0 \%$ & $6.2 \%$ & $6.4 \%$ \\
\hline Asian & $10.6 \%$ & $8.7 \%$ & $6.5 \%$ \\
\hline Hispanic & $7.9 \%$ & $8.3 \%$ & $5.8 \%$ \\
\hline Married & $61.7 \%$ & $51.6 \%$ & $57.7 \%$ \\
\hline Masters or higher & $36.5 \%$ & $26.9 \%$ & $46.3 \%$ \\
\hline All core arts majors & $5.4 \%$ & & \\
\hline Fine arts & $1.2 \%$ & & \\
\hline $\begin{array}{l}\text { Commercial art and } \\
\text { graphic design }\end{array}$ & $1.1 \%$ & & \\
\hline Music & $0.9 \%$ & & \\
\hline Architecture & $0.8 \%$ & & \\
\hline Drama and theater arts & $0.5 \%$ & & \\
\hline $\begin{array}{l}\text { Film, video, and } \\
\text { photographic arts }\end{array}$ & $0.4 \%$ & & \\
\hline Art history & $0.3 \%$ & & \\
\hline Studio arts & $0.2 \%$ & & \\
\hline Visual and performing arts & $0.2 \%$ & & \\
\hline Miscellaneous fine arts & $0.0 \%$ & & \\
\hline All extended arts majors & $4.3 \%$ & & \\
\hline $\begin{array}{l}\text { English lang., literature, } \\
\text { composition, and speech }\end{array}$ & $3.3 \%$ & & \\
\hline Art and music education & $0.6 \%$ & & \\
\hline Language and drama edu. & $0.5 \%$ & & \\
\hline $\begin{array}{l}\text { STEM and other creative } \\
\text { majors }\end{array}$ & $69.4 \%$ & & \\
\hline Engineering majors & $8.2 \%$ & & \\
\hline Science majors & $8.4 \%$ & & \\
\hline Social science majors & $8.6 \%$ & & \\
\hline $\begin{array}{l}\text { Business and economics } \\
\text { majors }\end{array}$ & $24.3 \%$ & & \\
\hline $\begin{array}{l}\text { Computer, math, and stats } \\
\text { majors }\end{array}$ & $5.6 \%$ & & \\
\hline Non-art education majors & $9.7 \%$ & & \\
\hline Communication majors & $4.6 \%$ & & \\
\hline Observations & $2,617,082$ & 141,758 & 119,128 \\
\hline Weight total & $52.4 \mathrm{M}$ & $2.8 \mathrm{M}$ & $2.3 \mathrm{M}$ \\
\hline
\end{tabular}

\footnotetext{
${ }^{a}$ The sample is restricted to those who have graduated with at least a bachelor's degree and are in the labor force. Sampling weights are used in calculations
}

Core art majors account for $40 \%$ of workers with bachelor's degrees in the entrepreneurial arts and entertainment occupations. A large segment comes from graphic design, architecture, and fine arts majors. Another $10 \%$ of artists and entertainers have degrees in an extended arts major. Those with a degree in literature or composition account for a large segment of this group (80\%).

There are three additional entrepreneurial occupation groups in which core arts majors account for sizeable shares of workers. Core arts majors account for onequarter of college educated workers in entrepreneurial production occupations, most common of which are graduates with degrees in fine arts and graphic design. Core arts majors also account for more than $10 \%$ of workers in both entrepreneurial computer and entrepreneurial educator occupations. Graphic design majors account for about half of core arts majors in the entrepreneurial computer occupations, while music majors account for almost half of core arts majors in the entrepreneurial education occupations. Among STEM majors, computer majors account for almost one-quarter of workers in entrepreneurial computer occupations. Almost $13 \%$ of web developers are communication majors, and almost $9 \%$ are social science majors. The STEM majors comprise more of the entrepreneurial educator occupation than core arts majors. Non-art education majors account for close to $20 \%$ of those in this occupation.

\subsection{Innovation}

We define innovation based on intellectual property (IP) creation. We define IP intensive industries as either copyright, patent, or trademark intensive based on a joint report of the Economics \& Statistics Administration and the U.S. Patent and Trademark Office (Economics and Statistics Administration and U.S. Patent and Trademark Office 2016). For our analysis, we focus on only those industries that are copyright intensive. We do this for multiple reasons. First, while patents and copyrights are innovative works directly, trademarks indirectly promote innovation through their ability to allow brands to build reputations and become recognizable to consumers. Second, while patents are innovative works, arts majors are unlikely to be directly involved in the creation of physical inventions. Although we restrict our analysis to copyright-intensive 
Table 2 Distribution of arts majors in entrepreneurial occupations

\begin{tabular}{|c|c|c|c|c|c|c|c|c|}
\hline \multirow[b]{2}{*}{$\begin{array}{c}\text { Entrepreneurial } \\
\text { occupation }\end{array}$} & \multirow[b]{2}{*}{$\begin{array}{r}\text { Core arts } \\
\text { majors }\end{array}$} & \multirow[b]{2}{*}{$\begin{array}{l}\text { Extended } \\
\text { arts majors }\end{array}$} & \multicolumn{6}{|c|}{ Core arts majors } \\
\hline & & & Fine art & Drama & Music & $\begin{array}{l}\text { Visual and } \\
\text { performing art }\end{array}$ & $\begin{array}{l}\text { Graphic } \\
\text { design }\end{array}$ & $\begin{array}{l}\text { Film, video, and } \\
\text { photography }\end{array}$ \\
\hline Manager & $4.87 \%$ & $2.90 \%$ & $0.93 \%$ & $0.37 \%$ & $0.55 \%$ & $0.08 \%$ & $0.85 \%$ & $0.28 \%$ \\
\hline $\begin{array}{l}\text { Business } \\
\text { Operations }\end{array}$ & $3.73 \%$ & $3.65 \%$ & $0.70 \%$ & $0.46 \%$ & $0.67 \%$ & $0.07 \%$ & $0.62 \%$ & $0.23 \%$ \\
\hline Finance & $2.08 \%$ & $2.77 \%$ & $0.46 \%$ & $0.16 \%$ & $0.42 \%$ & $0.05 \%$ & $0.36 \%$ & $0.11 \%$ \\
\hline Computer & $17.83 \%$ & $6.30 \%$ & $4.53 \%$ & $0.68 \%$ & $1.32 \%$ & $0.41 \%$ & $8.14 \%$ & $1.24 \%$ \\
\hline Legal & $2.14 \%$ & $8.69 \%$ & $0.34 \%$ & $0.37 \%$ & $0.51 \%$ & $0.06 \%$ & $0.10 \%$ & $0.14 \%$ \\
\hline Educator & $14.46 \%$ & $9.36 \%$ & $2.07 \%$ & $1.36 \%$ & $7.72 \%$ & $1.39 \%$ & $0.82 \%$ & $0.32 \%$ \\
\hline $\begin{array}{l}\text { Arts and } \\
\text { entertainment }\end{array}$ & $40.25 \%$ & $9.09 \%$ & $7.16 \%$ & $2.43 \%$ & $4.05 \%$ & $0.64 \%$ & $12.36 \%$ & $3.27 \%$ \\
\hline Medical & $1.76 \%$ & $2.36 \%$ & $0.48 \%$ & $0.19 \%$ & $0.43 \%$ & $0.11 \%$ & $0.13 \%$ & $0.07 \%$ \\
\hline $\begin{array}{l}\text { Cleaning } \\
\text { services }\end{array}$ & $6.28 \%$ & $2.96 \%$ & $1.65 \%$ & $0.29 \%$ & $0.77 \%$ & $0.06 \%$ & $1.07 \%$ & $0.18 \%$ \\
\hline $\begin{array}{l}\text { Personal } \\
\text { services }\end{array}$ & $7.84 \%$ & $4.80 \%$ & $2.13 \%$ & $1.18 \%$ & $0.87 \%$ & $0.42 \%$ & $1.63 \%$ & $0.48 \%$ \\
\hline Sales & $3.96 \%$ & $3.43 \%$ & $1.00 \%$ & $0.37 \%$ & $0.55 \%$ & $0.08 \%$ & $0.87 \%$ & $0.25 \%$ \\
\hline Farmers & $3.57 \%$ & $3.80 \%$ & $1.43 \%$ & $1.09 \%$ & $0.40 \%$ & $0.00 \%$ & $0.34 \%$ & $0.16 \%$ \\
\hline Construction & $8.53 \%$ & $2.35 \%$ & $2.55 \%$ & $0.74 \%$ & $0.78 \%$ & $0.07 \%$ & $1.26 \%$ & $0.37 \%$ \\
\hline Installers & $7.26 \%$ & $3.33 \%$ & $1.27 \%$ & $0.55 \%$ & $3.21 \%$ & $0.24 \%$ & $0.68 \%$ & $0.72 \%$ \\
\hline Production & $25.59 \%$ & $4.45 \%$ & $9.49 \%$ & $1.52 \%$ & $1.74 \%$ & $0.69 \%$ & $6.46 \%$ & $0.90 \%$ \\
\hline \multirow[t]{2}{*}{ Transportation } & $4.22 \%$ & $3.60 \%$ & $1.01 \%$ & $0.59 \%$ & $0.67 \%$ & $0.07 \%$ & $0.72 \%$ & $0.27 \%$ \\
\hline & \multicolumn{4}{|c|}{ Core arts majors } & \multicolumn{4}{|c|}{ Extended arts majors } \\
\hline $\begin{array}{l}\text { Entrepreneurial } \\
\text { occupation }\end{array}$ & Art history & Studio arts & $\begin{array}{l}\text { Misc. } \\
\text { fine arts }\end{array}$ & Architecture & $\begin{array}{c}\text { Language and } \\
\text { drama ed. }\end{array}$ & $\begin{array}{l}\text { Art and } \\
\text { music ed. }\end{array}$ & \multicolumn{2}{|c|}{$\begin{array}{l}\text { Literature } \\
\text { and composition }\end{array}$} \\
\hline Manager & $0.22 \%$ & $0.14 \%$ & $0.03 \%$ & $1.53 \%$ & $0.17 \%$ & $0.20 \%$ & $2.53 \%$ & \\
\hline $\begin{array}{l}\text { Business } \\
\text { operations }\end{array}$ & $0.26 \%$ & $0.10 \%$ & $0.07 \%$ & $0.61 \%$ & $0.18 \%$ & $0.15 \%$ & $3.33 \%$ & \\
\hline Finance & $0.17 \%$ & $0.06 \%$ & $0.01 \%$ & $0.37 \%$ & $0.20 \%$ & $0.21 \%$ & $2.36 \%$ & \\
\hline Computer & $0.30 \%$ & $0.93 \%$ & $0.18 \%$ & $0.66 \%$ & $0.30 \%$ & $0.33 \%$ & $5.68 \%$ & \\
\hline Legal & $0.36 \%$ & $0.06 \%$ & $0.03 \%$ & $0.23 \%$ & $0.14 \%$ & $0.10 \%$ & $8.45 \%$ & \\
\hline Educator & $0.47 \%$ & $0.33 \%$ & $0.05 \%$ & $0.32 \%$ & $1.23 \%$ & $3.27 \%$ & $4.91 \%$ & \\
\hline $\begin{array}{l}\text { Arts and } \\
\text { entertainment }\end{array}$ & $0.83 \%$ & $1.14 \%$ & $0.17 \%$ & $9.26 \%$ & $0.34 \%$ & $1.29 \%$ & $7.49 \%$ & \\
\hline Medical & $0.15 \%$ & $0.08 \%$ & $0.01 \%$ & $0.14 \%$ & $0.12 \%$ & $0.10 \%$ & $2.15 \%$ & \\
\hline $\begin{array}{l}\text { Cleaning } \\
\text { services }\end{array}$ & $0.14 \%$ & $0.30 \%$ & $0.02 \%$ & $1.92 \%$ & $0.25 \%$ & $0.36 \%$ & $2.37 \%$ & \\
\hline $\begin{array}{l}\text { Personal } \\
\text { services }\end{array}$ & $0.47 \%$ & $0.43 \%$ & $0.09 \%$ & $0.40 \%$ & $0.66 \%$ & $0.67 \%$ & $3.49 \%$ & \\
\hline Sales & $0.24 \%$ & $0.13 \%$ & $0.02 \%$ & $0.58 \%$ & $0.30 \%$ & $0.27 \%$ & $2.86 \%$ & \\
\hline Farmers & $0.00 \%$ & $0.17 \%$ & $0.00 \%$ & $0.00 \%$ & $0.06 \%$ & $2.16 \%$ & $1.58 \%$ & \\
\hline Construction & $0.15 \%$ & $0.44 \%$ & $0.04 \%$ & $2.30 \%$ & $0.18 \%$ & $0.32 \%$ & $1.85 \%$ & \\
\hline Installers & $0.05 \%$ & $0.30 \%$ & $0.04 \%$ & $0.44 \%$ & $0.18 \%$ & $1.70 \%$ & $1.45 \%$ & \\
\hline Production & $0.90 \%$ & $2.30 \%$ & $0.36 \%$ & $2.06 \%$ & $0.59 \%$ & $1.23 \%$ & $2.76 \%$ & \\
\hline Transportation & $0.11 \%$ & $0.10 \%$ & $0.06 \%$ & $0.63 \%$ & $0.20 \%$ & $0.22 \%$ & $3.19 \%$ & \\
\hline
\end{tabular}


Table 3 Distribution of non-art creative majors in entrepreneurial occupations

\begin{tabular}{|c|c|c|c|c|c|c|}
\hline \multirow[b]{2}{*}{ Entrepreneurial occupation } & \multicolumn{3}{|c|}{ STEM majors } & \multicolumn{3}{|c|}{ Other creative majors } \\
\hline & Computer & Engineering & Science & Communication & Non-art education & Social science \\
\hline Manager & $3.98 \%$ & $11.40 \%$ & $5.75 \%$ & $4.17 \%$ & $4.64 \%$ & $12.58 \%$ \\
\hline Business operations & $8.50 \%$ & $11.04 \%$ & $7.32 \%$ & $4.93 \%$ & $3.42 \%$ & $15.60 \%$ \\
\hline Finance & $3.71 \%$ & $4.74 \%$ & $3.81 \%$ & $3.38 \%$ & $3.30 \%$ & $16.48 \%$ \\
\hline Computer & $22.62 \%$ & $6.29 \%$ & $4.65 \%$ & $12.80 \%$ & $1.70 \%$ & $8.88 \%$ \\
\hline Legal & $2.06 \%$ & $3.78 \%$ & $4.77 \%$ & $4.48 \%$ & $1.95 \%$ & $43.96 \%$ \\
\hline Educator & $4.00 \%$ & $3.23 \%$ & $7.13 \%$ & $4.18 \%$ & $18.50 \%$ & $10.05 \%$ \\
\hline Arts and entertainment & $4.12 \%$ & $4.65 \%$ & $3.18 \%$ & $14.05 \%$ & $3.14 \%$ & $7.62 \%$ \\
\hline Medical & $1.77 \%$ & $3.09 \%$ & $49.55 \%$ & $0.91 \%$ & $2.23 \%$ & $5.76 \%$ \\
\hline Cleaning services & $3.41 \%$ & $5.15 \%$ & $6.48 \%$ & $3.45 \%$ & $11.08 \%$ & $9.86 \%$ \\
\hline Personal services & $2.53 \%$ & $1.99 \%$ & $6.14 \%$ & $4.98 \%$ & $16.22 \%$ & $8.96 \%$ \\
\hline Sales & $3.52 \%$ & $5.17 \%$ & $4.92 \%$ & $6.14 \%$ & $5.84 \%$ & $13.36 \%$ \\
\hline Farmers & $4.05 \%$ & $5.41 \%$ & $13.08 \%$ & $0.64 \%$ & $7.87 \%$ & $12.87 \%$ \\
\hline Construction & $3.96 \%$ & $14.99 \%$ & $6.73 \%$ & $3.07 \%$ & $6.64 \%$ & $9.87 \%$ \\
\hline Installers & $5.27 \%$ & $19.11 \%$ & $6.92 \%$ & $3.75 \%$ & $5.04 \%$ & $6.85 \%$ \\
\hline Production & $3.73 \%$ & $5.87 \%$ & $5.95 \%$ & $3.36 \%$ & $9.32 \%$ & $9.45 \%$ \\
\hline Transportation & $6.74 \%$ & $10.46 \%$ & $6.31 \%$ & $3.99 \%$ & $7.01 \%$ & $14.14 \%$ \\
\hline
\end{tabular}

industries, we present results for patent and trademark intensive industries in the online appendix.

The ACS reports just over 250 unique industries using the North American Industry Classification System (NAICS) code. Thirteen of those industries are identified as copyright intensive. These industries include newspaper, periodical, book, and directory publishers; software publishers; motion picture and video industries; sound recording industries; radio and television broadcasting; cable and other subscription programming; other information services; specialized design services; computer systems design and related services; advertising and related services; other professional and technical services; performing arts companies; and independent artists, writers, and performers ${ }^{7}$ (Economics and Statistics Administration and U.S. Patent and Trademark Office 2016). Some are newer, coming into relevance with the rise of the internet economy. A number of these industries are closely linked to artistic output; $8.2 \%$ of college graduates work in one of the copyright-intensive industries. ${ }^{8}$

\footnotetext{
${ }^{7}$ The corresponding NAICS codes, respectively, are 5111, 5112, 5121, 5122, 5151, 5152, 5191, 5414, 5415, 5418, 5419, 7111, and 7115 .

${ }^{8}$ Table A - 5 gives a more detailed breakdown of the distribution of copyright workers across these industries in the ACS sample.
}

The following tables show the distribution of college graduates in the innovative copyright-intensive industries. Table 4 provides this information for both the core arts majors and the extended arts majors. Table 5 provides the same information for STEM majors and some other creative majors.

College graduates with at least one core arts major account for more than one quarter of all college graduates who work in four of the thirteen copyright-intensive industries. The greatest intensity is the specialized design services industry; over half of college graduates in this industry possess a core arts major. This industry includes businesses that provide interior, industrial, and graphic design services. More than half of core arts majors who work in this industry are graphic design majors. None of the STEM or other creative major groupings individually account for greater than $10 \%$ of workers in the specialized design services industry.

Core arts majors account for around 30\% of graduates in three additional copyright-intensive industries. The first are the performing arts companies and independent artists, writers, and performers (artists and performers) industries. These include venues that produce or organize and promote live presentations of the performances of actors and actresses, singers, dancers, musical groups and artists, and the independent (freelance) artists. Music majors are one- 
Table 4 Distribution of arts majors in innovative industries

\begin{tabular}{|c|c|c|c|c|c|c|c|c|}
\hline \multirow[b]{2}{*}{$\begin{array}{l}\text { Copyright } \\
\text { industries }\end{array}$} & \multirow[b]{2}{*}{$\begin{array}{r}\text { Core arts } \\
\text { majors }\end{array}$} & \multirow[b]{2}{*}{$\begin{array}{l}\text { Extended arts } \\
\text { majors }\end{array}$} & \multicolumn{6}{|c|}{ Core arts majors } \\
\hline & & & Fine art & Drama & Music & $\begin{array}{l}\text { Visual and } \\
\text { performing art }\end{array}$ & $\begin{array}{l}\text { Graphic } \\
\text { design }\end{array}$ & $\begin{array}{c}\text { Film, video, and } \\
\text { photography }\end{array}$ \\
\hline Newspaper & $8.71 \%$ & $12.34 \%$ & $2.65 \%$ & $0.39 \%$ & $0.57 \%$ & $0.13 \%$ & $3.43 \%$ & $0.99 \%$ \\
\hline Software & $5.12 \%$ & $3.26 \%$ & $1.25 \%$ & $0.41 \%$ & $0.67 \%$ & $0.14 \%$ & $1.30 \%$ & $0.43 \%$ \\
\hline $\begin{array}{l}\text { Movie and } \\
\text { video }\end{array}$ & $30.24 \%$ & $6.61 \%$ & $5.22 \%$ & $6.25 \%$ & $2.15 \%$ & $0.75 \%$ & $2.47 \%$ & $12.42 \%$ \\
\hline $\begin{array}{l}\text { Sound } \\
\text { recording }\end{array}$ & $29.91 \%$ & $7.99 \%$ & $2.71 \%$ & $2.40 \%$ & $20.71 \%$ & $0.87 \%$ & $1.34 \%$ & $1.20 \%$ \\
\hline Radio/TV & $9.01 \%$ & $5.06 \%$ & $1.73 \%$ & $1.33 \%$ & $1.02 \%$ & $0.23 \%$ & $1.46 \%$ & $2.49 \%$ \\
\hline Internet & $7.20 \%$ & $5.98 \%$ & $1.35 \%$ & $0.64 \%$ & $0.91 \%$ & $0.27 \%$ & $1.98 \%$ & $1.08 \%$ \\
\hline Special design & $53.17 \%$ & $3.72 \%$ & $11.06 \%$ & $1.32 \%$ & $0.58 \%$ & $0.51 \%$ & $31.94 \%$ & $1.04 \%$ \\
\hline $\begin{array}{l}\text { Computer } \\
\text { systems }\end{array}$ & $3.60 \%$ & $2.65 \%$ & $0.80 \%$ & $0.26 \%$ & $0.58 \%$ & $0.09 \%$ & $1.01 \%$ & $0.31 \%$ \\
\hline Advertising & $13.58 \%$ & $6.29 \%$ & $3.45 \%$ & $0.84 \%$ & $0.72 \%$ & $0.36 \%$ & $5.60 \%$ & $1.23 \%$ \\
\hline $\begin{array}{l}\text { Other prof. } \\
\text { services }\end{array}$ & $14.77 \%$ & $5.83 \%$ & $3.59 \%$ & $0.82 \%$ & $0.84 \%$ & $0.36 \%$ & $2.63 \%$ & $4.90 \%$ \\
\hline $\begin{array}{l}\text { Artists and } \\
\text { performers }\end{array}$ & $30.61 \%$ & $10.22 \%$ & $6.47 \%$ & $6.78 \%$ & $9.94 \%$ & $1.31 \%$ & $1.93 \%$ & $2.11 \%$ \\
\hline $\begin{array}{l}\text { Periodicals } \\
\text { and books }\end{array}$ & $11.49 \% \%$ & $16.49 \%$ & $2.80 \%$ & $0.92 \%$ & $1.02 \%$ & $0.20 \%$ & $4.01 \%$ & $1.30 \%$ \\
\hline \multirow[t]{2}{*}{ Other info } & $5.73 \%$ & $5.75 \%$ & $1.05 \%$ & $0.59 \%$ & $0.50 \%$ & $0.07 \%$ & $1.31 \%$ & $1.46 \%$ \\
\hline & \multicolumn{4}{|c|}{ Core arts majors } & \multicolumn{4}{|c|}{ Extended arts majors } \\
\hline $\begin{array}{l}\text { Copyright } \\
\text { industries }\end{array}$ & Art history & Studio arts & $\begin{array}{l}\text { Misc. } \\
\text { fine arts }\end{array}$ & Architecture & $\begin{array}{l}\text { Language and } \\
\text { drama ed. }\end{array}$ & $\begin{array}{l}\text { Art and } \\
\text { music ed. }\end{array}$ & \multicolumn{2}{|c|}{$\begin{array}{l}\text { Literature } \\
\text { and composition }\end{array}$} \\
\hline Newspaper & $0.24 \%$ & $0.27 \%$ & $0.06 \%$ & $0.28 \%$ & $0.59 \%$ & $0.37 \%$ & \multicolumn{2}{|l|}{$11.40 \%$} \\
\hline Software & $0.37 \%$ & $0.07 \%$ & $0.21 \%$ & $0.37 \%$ & $0.08 \%$ & $0.08 \%$ & \multicolumn{2}{|l|}{$3.10 \%$} \\
\hline $\begin{array}{l}\text { Movie and } \\
\text { video }\end{array}$ & $0.63 \%$ & $0.48 \%$ & $0.25 \%$ & $0.72 \%$ & $0.12 \%$ & $0.31 \%$ & \multicolumn{2}{|l|}{$6.22 \%$} \\
\hline $\begin{array}{l}\text { Sound } \\
\text { recording }\end{array}$ & $0.52 \%$ & $0.25 \%$ & $0.15 \%$ & $0.58 \%$ & $0.47 \%$ & $1.29 \%$ & \multicolumn{2}{|l|}{$6.23 \%$} \\
\hline Radio/TV & $0.32 \%$ & $0.16 \%$ & $0.11 \%$ & $0.33 \%$ & $0.08 \%$ & $0.30 \%$ & \multicolumn{2}{|l|}{$4.68 \%$} \\
\hline Internet & $0.31 \%$ & $0.20 \%$ & $0.12 \%$ & $0.48 \%$ & $0.09 \%$ & $0.14 \%$ & \multicolumn{2}{|l|}{$5.76 \%$} \\
\hline Special design & $1.43 \%$ & $1.53 \%$ & $0.24 \%$ & $5.10 \%$ & $0.14 \%$ & $0.56 \%$ & \multicolumn{2}{|l|}{$3.05 \%$} \\
\hline $\begin{array}{l}\text { Computer } \\
\text { systems }\end{array}$ & $0.14 \%$ & $0.13 \%$ & $0.07 \%$ & $0.31 \%$ & $0.11 \%$ & $0.14 \%$ & \multicolumn{2}{|l|}{$2.40 \%$} \\
\hline Advertising & $0.70 \%$ & $0.51 \%$ & $0.10 \%$ & $0.47 \%$ & $0.18 \%$ & $0.13 \%$ & \multicolumn{2}{|l|}{$5.98 \%$} \\
\hline $\begin{array}{l}\text { Other prof. } \\
\text { services }\end{array}$ & $0.62 \%$ & $0.74 \%$ & $0.14 \%$ & $0.74 \%$ & $0.32 \%$ & $0.38 \%$ & \multicolumn{2}{|l|}{$5.14 \%$} \\
\hline $\begin{array}{l}\text { Artists and } \\
\text { performers }\end{array}$ & $0.83 \%$ & $1.26 \%$ & $0.33 \%$ & $0.55 \%$ & $0.44 \%$ & $1.67 \%$ & \multicolumn{2}{|l|}{$8.15 \%$} \\
\hline $\begin{array}{l}\text { Periodicals } \\
\text { and books }\end{array}$ & $0.68 \%$ & $0.57 \%$ & $0.08 \%$ & $0.35 \%$ & $0.60 \%$ & $0.35 \%$ & \multicolumn{2}{|l|}{$15.55 \%$} \\
\hline Other info & $0.21 \%$ & $0.18 \%$ & $0.00 \%$ & $0.38 \%$ & $0.40 \%$ & $0.06 \%$ & \multicolumn{2}{|l|}{$5.29 \%$} \\
\hline
\end{tabular}

third of these core arts majors; fine art and drama and theater arts majors each account for another $20 \%$ of them.
The second of these three is the motion picture and video industries. This industry group includes businesses that are 
Table 5 Distribution of non-art creative majors in innovative industries

\begin{tabular}{|c|c|c|c|c|c|c|}
\hline \multirow[b]{2}{*}{ Copyright industries } & \multicolumn{3}{|c|}{ STEM majors } & \multicolumn{3}{|c|}{ Other creative majors } \\
\hline & Computer & Engineering & Science & Communication & Non-art education & Social science \\
\hline Newspaper & $3.86 \%$ & $2.80 \%$ & $2.78 \%$ & $34.86 \%$ & $3.71 \%$ & $11.78 \%$ \\
\hline Software & $22.05 \%$ & $18.38 \%$ & $5.78 \%$ & $5.71 \%$ & $1.53 \%$ & $9.83 \%$ \\
\hline Movie and video & $6.78 \%$ & $3.92 \%$ & $2.69 \%$ & $23.66 \%$ & $1.85 \%$ & $9.78 \%$ \\
\hline Sound recording & $7.32 \%$ & $5.39 \%$ & $2.93 \%$ & $13.96 \%$ & $0.94 \%$ & $8.73 \%$ \\
\hline Radio/TV & $8.19 \%$ & $5.01 \%$ & $2.88 \%$ & $33.93 \%$ & $2.16 \%$ & $10.69 \%$ \\
\hline Internet & $21.66 \%$ & $13.18 \%$ & $5.15 \%$ & $10.39 \%$ & $1.63 \%$ & $12.70 \%$ \\
\hline Special design & $3.78 \%$ & $4.51 \%$ & $2.56 \%$ & $6.53 \%$ & $2.81 \%$ & $6.10 \%$ \\
\hline Computer systems & $29.11 \%$ & $19.58 \%$ & $5.93 \%$ & $4.02 \%$ & $1.57 \%$ & $8.13 \%$ \\
\hline Advertising & $5.08 \%$ & $2.72 \%$ & $2.66 \%$ & $25.74 \%$ & $2.13 \%$ & $11.62 \%$ \\
\hline Other prof. services & $5.51 \%$ & $5.11 \%$ & $5.89 \%$ & $10.18 \%$ & $4.29 \%$ & $12.73 \%$ \\
\hline Artists and performers & $3.05 \%$ & $2.91 \%$ & $3.84 \%$ & $12.00 \%$ & $4.16 \%$ & $10.27 \%$ \\
\hline Periodicals and books & $5.59 \%$ & $3.14 \%$ & $3.84 \%$ & $16.29 \%$ & $4.02 \%$ & $12.87 \%$ \\
\hline Other info & $15.70 \%$ & $9.44 \%$ & $5.25 \%$ & $15.04 \%$ & $1.48 \%$ & $15.04 \%$ \\
\hline
\end{tabular}

primarily engaged in the production and/or distribution of movies, videos, television programs, or commercials, in the showing of movies; or providing postproduction and related services. Film, video, and photography majors account for $40 \%$ of the core arts majors working in this industry group. Drama and fine arts majors combined to account for about an additional $40 \%$ of these workers. Beyond core arts majors, almost one-quarter of those with college degrees who work in these industries are communication majors. The last of these three is the sound recording industries group. This industry group includes businesses that produce and distribute musical recordings, publish music, or provide sound recording and related services. More than two-thirds of core arts majors working in these industries are music majors. None of the STEM majors account for as much as $8 \%$ of the college graduate workers in this industry group; communication majors account for $14 \%$.

Among the remaining innovative industry groups, other professional and technical services, ${ }^{9}$ advertising and related services, and periodical, book, and directory publishers have core arts majors accounting for between 10 and $15 \%$ of the workers with college degrees. In the remaining innovative copyright industries, neither core arts majors nor extended arts majors are well represented. However, some of the non-arts creative majors are well represented within these industries. Computer,

\footnotetext{
$\overline{{ }^{9} \text { ACS code } 7490}$ or NAICS code 5419
}

engineering, communication, and social science majors are well represented in these industries.

\section{Empirical methodology}

The descriptive evidence presented thus far suggests a substantial role for arts majors as entrepreneurs and innovators within the economy. Specifically, $44 \%$ of core arts majors are employed in an entrepreneurial occupation or innovative industry, with $37.5 \%$ employed in entrepreneurial occupations and $19.6 \%$ employed in copyright-intensive industries. Logistic regressions will be used to complement this descriptive evidence. This will allow us to test for differences in the employment of arts majors in entrepreneurial occupations and innovative industries relative to STEM majors, other creative majors, and non-creative majors, holding constant demographic and employment-related characteristics.

First, logistic regressions are estimated with an indicator for entrepreneurial occupation as the dependent variable. The estimating equation considered is

$$
\begin{aligned}
\text { Entrepreneur }_{i}= & \beta_{0}+\beta_{1} \text { CoreArts }_{i}+\beta_{2} \text { ExtendedArts }_{i} \\
& +\beta_{\boldsymbol{M}} \boldsymbol{M}_{i}+\beta_{\boldsymbol{D}} \boldsymbol{D}_{i}+\beta_{\boldsymbol{E}} \boldsymbol{E}_{i}+\varepsilon_{i}
\end{aligned}
$$

where CoreArts is a binary variable indicating that the individual majored in a core arts major and ExtendedArts 
is a binary variable indicating that the individual majored in an extended arts major. The vector $\boldsymbol{M}$ is a group of binary variables indicating the various non-arts creative major groupings. Demographic controls, the vector $\boldsymbol{D}$, include age and age-squared, binary variables indicating married, white, Black, Asian, Hispanic, and male, as well as an interaction of male and married. Employment related controls, the vector $\boldsymbol{E}$, include indicators for part-time employment and having a degree beyond a bachelor's degree, as well as regional indicators. Additionally, one regression includes binary variables indicating the broad occupational groupings as identified in Online Appendix Table A -2 . Majoring in the arts could increase the likelihood of working in an occupational grouping where entrepreneurship is common, or it could increase the likelihood of working in an entrepreneurial occupation within an occupational grouping. This regression will allow us to parse out those two effects.

A logistic regression is then estimated with an indicator for employment in innovative industries as the dependent variable. The estimating equation to be considered is

$$
\begin{aligned}
\text { Innovator }_{i}= & \beta_{0}+\beta_{1} \text { CoreArts }_{i}+\beta_{2} \text { ExtendedArts }_{i} \\
& +\beta_{\boldsymbol{M}} \boldsymbol{M}_{i}+\beta_{\boldsymbol{D}} \boldsymbol{D}_{i}+\beta_{\boldsymbol{E}} \boldsymbol{E}_{i}+\gamma_{i} .
\end{aligned}
$$

where the independent variables mirror those in the entrepreneur regressions.

\section{Results}

Logistic regression results testing for the impact of being an arts major on employment in entrepreneurial occupations and innovative industries are presented in Table 6. In the first two regressions, the dependent variable is Entrepreneur. In the third regression, the dependent variable is Innovator. The coefficients presented in the Table 6 are marginal effects estimated at means.

The regression results suggest a substantial role for art majors as entrepreneurs and innovators. In the first specification, being a core arts major is associated with a 22.0 percentage point increase in employment in an entrepreneurial occupation relative to non-creative majors. As about $19.4 \%$ of the population of employed college graduates are employed in an entrepreneurial occupation, majoring in the core arts more than doubles this likelihood. While smaller, majoring in an extended arts field increases this likelihood by 4.1 percentage points. The impact of majoring in the core arts is substantial in comparison to having a STEM or other creative major. Among other creative majors, the coefficient on communication majors is highest at 8.6 percentage points. Among STEM majors, the coefficient on science majors is highest at 8.4 percentage points. The second specification adds controls for broad occupational groupings. When adding these controls, the coefficient on core arts major falls to 8.0 percentage points. As such, about twothirds of the impact of being a core arts major on entrepreneurship is due to an increased likelihood of being employed in an entrepreneurial occupation group, and one-third is due to an increased likelihood of entrepreneurship within occupational groupings.

The third specification tests for the impact of majoring in the arts on employment in innovative industries. ${ }^{10}$ Majoring in the core arts is associated with a 13.9 percentage point increase in employment in copyright-intensive industries. As $8 \%$ of all college graduates are employed in copyright-intensive industries, core arts majors are more than twice as likely to be employed in these industries. Majoring in an extended arts field is associated with a 6.3 percentage point increase in the likelihood of innovative employment. Two other groups of creative majors, computer, math, and stats majors at 18.5 percentage points and communication majors at 15.3 percentage points are more likely than core arts majors to be employed in these industries.

Majoring in the arts also increases their likelihood of succeeding in these areas. Online Appendix Table A - 6 presents the results of a logistic regression where the dependent variable indicates whether a worker has above average earnings in an entrepreneurial occupation or innovative industry. Of note are the positive and significant coefficients on the arts majors variables. These positive earnings impacts may also explain the motivation for arts majors to choose work as entrepreneurs and innovators.

\section{Conclusions}

This paper investigates the role college graduates with arts majors play as entrepreneurs and innovators in the US economy. As creativity is deeply intertwined with entrepreneurship and innovation, we hypothesize that

\footnotetext{
${ }^{10}$ Comparable results for employment in patent and trademark intensive industries are presented in Online Appendix Table A - 7 .
} 
Table 6 Logit regression: dependent variables are binaries for whether or not employed in entrepreneurial occupation, innovative industry

\begin{tabular}{|c|c|c|c|}
\hline Major grouping & Entrepreneurial occupation & Entrepreneurial occupation & Innovative industry \\
\hline Core arts majors & $0.220 * * *(0.000)$ & $0.080 * * *(0.000)$ & $0.139 * * *(0.000)$ \\
\hline Extended arts majors & $0.041 * * *(0.000)$ & $0.020 * * *(0.000)$ & $0.063 * * *(0.000)$ \\
\hline Engineering & $-0.049 * * *(0.000)$ & $0.011 * * *(0.000)$ & $0.042 * * *(0.000)$ \\
\hline Science & $0.084 * * *(0.000)$ & $0.081 * * *(0.000)$ & $-0.001 * * *(0.000)$ \\
\hline Social science & $0.065 * * *(0.000)$ & $0.023 * * *(0.000)$ & $0.018 * * *(0.000)$ \\
\hline Business and economics & $0.032 * * *(0.000)$ & $0.025 * * *(0.000)$ & $0.016 * * *(0.000)$ \\
\hline Computer, math, and stats & $-0.049 * * *(0.000)$ & $0.007 * * *(0.000)$ & $0.185 * * *(0.000)$ \\
\hline Non-art education & $-0.076 * * *(0.000)$ & $-0.011 * * *(0.000)$ & $-0.033 * * *(0.000)$ \\
\hline Communication & $0.086 * * *(0.000)$ & $0.023 * * *(0.000)$ & $0.153 * * *(0.000)$ \\
\hline Demographic controls & Yes & Yes & Yes \\
\hline Occupational grouping indicators & No & Yes & No \\
\hline Observations & $2,533,410$ & $2,533,410$ & $2,533,410$ \\
\hline
\end{tabular}

${ }^{\text {a }}$ The sample is restricted to those who have graduated with at least a bachelor's degree, are in the labor force, and are employed. Coefficient estimates reported are marginal effects estimated at means. Standard errors are in parenthesis. Sampling weights are used in calculations. $* * *$ indicates $p<0.01$

the role for arts majors in these areas is substantial. Using the American Community Survey data, we test this hypothesis. We define entrepreneurial occupations as those in which self-employment is high, and innovative industries as those that are copyright intensive. We then identify a substantial role for arts majors in entrepreneurship and innovation. We find that majoring in the arts more than doubles the likelihood of working in an entrepreneurial occupation or innovative industry. We find that when compared to STEM and other creative majors, arts graduates compare favorably in their probability of working in these areas.

There are several reasons why these findings are important. First, entrepreneurship and innovation are important drivers of an economy; having a better understanding of who is playing these roles can help to inform policy geared at promoting these areas. Almost 20\% of college graduates work in entrepreneurial occupations and almost $10 \%$ work in innovative industries. Of core arts majors working in innovative industries, nearly half work in professional, scientific, and technical services industries, and more than a quarter work in information industries. While more than half of core arts majors working in entrepreneurial occupations work within arts, entertainment, and recreation, nearly $40 \%$ work in entrepreneurial occupations within management, education, and other fields.

Second, student loan debt in the USA is large and rising, and there has been a concern about funding students in fields for which job prospects are bleak. Job prospects and salary income within the arts and entertainment fields are not strong (Wassall and Alper 2018). While there is value in artistic creation itself, these findings suggest that arts majors obtain skills that are transferable so that many can work as entrepreneurs and innovators.

Third, the findings of this work have important policy implications. As arts majors play an important role in entrepreneurship and innovation, which are drivers of economic growth, these findings provide support for further investment in arts education. While our work focuses on the role of college graduates with degrees in the arts, investment in art education at the primary and secondary levels is necessary as well. Without exposure to the arts at the primary and secondary levels, it is unlikely that there would be a pipeline of students interested in majoring in the arts at the college level. Further, exposure at these earlier levels may also nurture creativity in students who do not ultimately pursue a college degree or a creative college field.

There is a growing body of work stressing the importance of entrepreneurship education within arts higher education programs (Bridgstock 2012; Pollard and Wilson 2013) as well as works providing guidance on how to do so (Hong et al. 2010; Toscher 2019). In light of this research, there is evidence that entrepreneurship education in arts higher education is growing (White 2013; Essig and Guevara 2016). Even among the share of arts majors that go on to work in the public school system, evidence suggests that entrepreneurial 
training leads to increased entrepreneurial activities in and outside the classroom (Hanson 2019).

A final policy implication of this work relates to the importance of interdisciplinarity in higher education. Recent work studying firms in the UK has found significant economic returns to combining arts and science skills (Siepel et al. 2016). Works looking at the returns to double majoring similarly suggest economic returns to pairing arts skills with science and other skillsets (Del Rossi and Hersch 2008; Alper and Wassall 2016). Our findings of significant percentages of arts majors working in entrepreneurial occupations and innovative industries outside of the arts suggest that this interdisciplinarity is valued by US firms as well.

While our findings take an important first step in identifying the role that arts majors play as entrepreneurs and innovators in the US economy, there are many important avenues for future research still to be explored. The size of the dataset allows for an analysis at a more granular level. Some major US cities are known as being hubs for technology and innovation, and some are known as being creative hubs. An understanding of where arts majors are most commonly playing roles as entrepreneurs and innovators, and how creative and innovative hubs may interact in determining this, could add value. Further, analyses of this nature looking at this issue outside the USA could be of value. Last, cost-benefit analyses to help inform policymakers about where resources dedicated to the arts could be most efficiently targeted would be important, especially in light of the economic crises experienced in the twenty-first century, notably the Great Recession and the coronavirus pandemic.

Data availability All data used in this study comes from publicly available sources.

\section{Compliance with ethical standards}

Conflict of interest The authors declare that they have no conflict of interest.

Code availability Not applicable.

\section{References}

Alper, N. \& Wassall, G. (2016). Double-majoring in the arts: cohort and related effects. 19th international conference on cultural economics. Conference Presentation.

Audretsch, D. B. (2003). Entrepreneurship: a survey of the literature. Enterprise Directorate-general European Commission,
Enterprise papers no. 14. https://op.europa.eu/en/publicationdetail/-/publication/e6e50a79-612b-4e88-b3c9-88f1 ff3f01 ee.

Baregheg, A., Rowley, J., \& Sambrook, S. (2009). Towards a multidisciplinary definition of innovation. Management Decision, 47(8), 1323-1339. https://doi.org/10.1108 /00251740910984578.

BFAMFAPhD. (2014). Artists report back: a national study on the lives of arts graduates and working artists. http://bfamfaphd. com/\#artists-report-back.

Bille, T., \& Jensen, S. (2018). Artistic education matters: survival in the arts occupations. Journal of Cultural Economics, 42, 23-43. https://doi.org/10.1007/s10824-016-9278-5.

Blanchflower, D. G. (2007). Entrepreneurship in the United States. IZA discussion paper 3130, Institute of Labor Economics (IZA). https://www.iza.org/en/publications/dp/3130 /entrepreneurship-in-the-united-states.

Blanchflower, D. G. \& Oswald, A. J. (2007). What makes a young entrepreneur? IZA Discussion Paper 3139. https://www.iza. org/publications/dp/3139/what-makes-a-youngentrepreneur.

Bridgstock, R. (2012). Not a dirty word: arts entrepreneurship and higher education. Arts \& Humanities in Higher Education, 12(2-3), 122-137. https://doi.org/10.1177 $/ 1474022212465725$.

Bujor, A., \& Avasilcai, S. (2014). Creative entrepreneurship in Europe: a framework of analysis. Fascicle of Management and Technological Engineering, 1, 151-156. https://doi. org/10.15660/AUOFMTE.2014-1.2960.

Carlsson, B. (1999). Small business, entrepreneurship, and industrial dynamics. In Z. Acs (Ed.), Are small firms important? (pp. 99-110). Boston and Dordrecht: Kluwer Academic Publishers.

Christnacht, C., Smith, A., \& Chenevert, R. (2018). Measuring entrepreneurship in the American community survey: a demographic and occupational profile of self-employed workers. SEHSD Working Paper Number 2018-28: 1-27. https://www.census.gov/library/working-papers/2018 /demo/SEHSD-WP2018-28.html.

Del Rossi, A. F., \& Hersch, J. (2008). Double your major, double your return? Economics of Education Review, 27, 375-386. https://doi.org/10.1016/j.econedurev.2007.03.001.

Economics \& Statistics Administration and U.S. Patent and Trademark Office. (2016). Intellectual property and the U.S. economy: 2016 Update. https://www.uspto.gov/sites/default/ files/documents/IPandtheUSEconomySept2016.pdf.

Essig, L., \& Guevara, J. (2016). A landscape of arts entrepreneurship in US higher education. Alliance for the arts in research universities: 1-67. https://herbergerinstitute.asu. edu/sites/default/files/a_landscape_of_arts entrepreneurship_in_us_higher_education_0.pdf.

Facts \& Data on Small Business and Entrepreneurship. (2018). https://sbecouncil.org/about-us/facts-and-data/.

Fairlie, R., Desai, S., \& Herrmann, A. J. (2019). 2017 National Report on early-stage entrepreneurship. Kauffman Indicators of Entrepreneurship: 1-32. https://indicators.kauffman. org/wp-content/uploads/sites/2/2019/02/2017-NationalReport-on-Early-Stage-Entrepreneurship-February-20191. pdf. 
Fölster, S. (2000). Do entrepreneurs create jobs? Small Business Economics, 14, 137-148. https://doi.org/10.1023 /A:1008141516160.

Frenette, A. \& Dowd, T. J. (2018). Who stays and who leaves? Arts education and the career trajectories of arts alumni in the United States. National Endowment for the Arts Working Paper 1-67. https://www.arts.gov/sites/default/files/ResearchArt-Works-ASU2.pdf.

Gerber, A., \& Childress, C. (2017). The economic world obverse: freedom through markets after arts education. American Behavioral Scientist, 61, 1532-1554. https://doi. org/10.1177/0002764217734275.

Hanson, J. (2019). Entrepreneurship among public school arts educators: the case of music teachers in New York state. Artivate: A Journal of Entrepreneurship in the Arts, 8(1), 45-66 http://artivate.org.

Hong, C., Essig, L., \& Bridgstock, R. (2010). The enterprising artist and the arts entrepreneur: emergent pedagogies for new disciplinary habits of mind. In book: Exploring More Signature Pedagogies, Publisher: Stylus, 68-81.

Innovation. (2020). Merriam-Webster.com Dictionary. https://www.merriam-webster.com/dictionary/innovation.

Kahn, S., La Mattina, G., \& MacGarvie, M. J. (2017). 'Misfits,' 'stars,' and immigrant entrepreneurship. Small Business Economics, 49, 533-557. https://doi.org/10.1007/s11187017-9848-8.

Kritikos, A. S. (2014). Entrepreneurs and their impact on jobs and economic growth. IZA World of Labor, 8, 1-10. https://doi. org/10.15185/izawol.8.

Lazear, E. P. (2005). Entrepreneurship. Journal of Labor Economics, 23(4), 649-680. https://doi.org/10.1086/491605.

Lechmann, D. S. J., \& Schnabel, C. (2014). Are the self-employed really jacks-of-all-trades? Testing the assumptions and implications of Lazear's theory of entrepreneurship with German data. Small Business Economics, 42, 59-76. https://doi. org/10.1007/s11187-012-9464-6.

Lena, J. C., Gaskill, S., Houghton, R. F., Lambert, A. D., Miller, A. L. \& Tepper, S. J. (2014). Making it work: the education and employment of recent arts graduates, SNAAP annual report 2014. Bloomington, IN: Center for Postsecondary Research, Indiana University, School of Education. http://snaap.indiana.edu/pdf/2014/SNAAP AR 2014.pdf.

Lindemann, D. J., Tepper, S. J., Gaskill, S., Jones, S. D., Kuh, G. D., Lambert, A. D., Lena, J., Miller, A. L., Park, K., Rudolph, E. B., \& Vanderwerp, L. (2012). Painting with broader strokes: reassessing the value of an arts education. Bloomington, IN: Indiana University and Vanderbilt University, Strategic National Arts Alumni Project. http://snaap.indiana. edu/pdf/SNAAP_Special\%20Report_1.pdf.

Nelson, B. (2012). The real definition of entrepreneur - and why it matters. Forbes. www.forbes.com/sites/brettnelson/2012/06 /05/the-real-definition-of-entrepreneur-and-why-itmatters/\#505bc1564456.

Park, W. G. (2010). The copyright dilemma: copyright systems, innovation, andEconomic development. Journal of International Affairs Editorial Board, 64(1), 53-68 http://www.jstor.org/stable/24385185.

Phillips, R. J. (2010). Arts entrepreneurship and economic development: can every city by "Austintacious"? Foundations and Trends in Entrepreneurship, 6(4), 239-313. https://doi. org/10.1561/0300000039.
Plotnikova, M., Romero, I., \& Martinez-Roman, J. A. (2016). Process innovation in small business: the self-employed as entrepreneurs. Small Business Economics, 47, 939-954. https://doi.org/10.1007/s11187-016-9743-8.

Pollard, V., \& Wilson, E. (2013). The "entrepreneurial mindset" in creative and performing arts higher education in Australia. Artivate: A Journal of Entrepreneurship in the Arts, 3(1), 3$22 \mathrm{http} / / /$ artivate.org.

Radich, A. (2014). Arts Entrepreneurship Blogathon - Day 1. https://blog.westaf.org/2014/05/arts-entrepreneurshipblogathon-day-1.html.

Rengers, M. (2002). Economic lives of artists: studies into careers and the labour market in the cultural sector. Utrecht: Utrecht University, Interunviersity Center for Social Science Theory and Methodology. https://dspace.library.uu.nl/handle/1874/815.

Siepel, J., Camerani, R., Pellegrino, B., \& Masucci, M. (2016). The fusion effect: the economics returns to combining arts and science skills. A Report for Nesta: 1-30. https://www. nesta.org.uk/report/the-fusion-effect-the-economic-returnsto-combining-arts-and-science-skills/\#: : text=Key\%20 findings, bring\%20radical\%20innovations $\% 20$ to $\% 20$ market.

Szaban, J., \& Skrzek-Lubasinska, M. (2018). Self-employment and entrepreneurship: a theoretical approach. Central European Management Journal, 26(2), 89-120. https://doi. org/10.7206/jmba.ce.2450-7814.230.

Teese, D. J. (2018). Profiting from innovation in the digital economy: enabling technologies, standards, and licensing models in the wireless world. Research Policy, 47, 1367-1387. https://doi.org/10.1016/j.respol.2017.01.015.

Tepper, S., \& Kuh, G. D. (2011). Let's get serious about cultivating creativity. The Chronicle of Higher Education Review. https://www.chronicle.com/article/lets-get-serious-aboutcultivating-creativity/.

Toscher, B. (2019). Entrepreneurial learning in arts entrepreneurship education: a conceptual framework. Artivate: A Journal of Entrepreneurship in the Arts, 8(1), 3-22 http://artivate.org.

Towse, R., Handke, C., \& Stepan, P. (2008). The economics of copyright law: a stockpile of the literature. Review of Economic Research on Copyright Issues, 5(1), 1-22 https://core.ac.uk/download/pdf/4897291.pdf.

Wassall, G. \& Alper, N. (2018). The importance of a college major in the arts to artistic success. National Endowment for the Arts Working Paper. https:/www.arts.gov/sites/default/files/ResearchArt-Works-Northeastern-rev.pdf.

What is Entrepreneurship?. (n.d.). www.startupusa.ord/what-isentrepreneurship/.

White, J. C. (2013). Barriers to recognizing arts entrepreneurship education as essential to professional arts training. Artivate: A Journal of Entrepreneurship in the Arts, 2(3), 28-39 http://artivate.org.

Woronkowicz, J., \& Noonan, D. (2019). Who Goes freelance? The determinants of self-employment for artists. Entrepreneurship Theory and Practice, 43(4), 651-672. https://doi.org/10.1177/1042258717728067.

Publisher's note Springer Nature remains neutral with regard to jurisdictional claims in published maps and institutional affiliations. 